\title{
CONTEMPORARY INDIA: A CASE OF NEW DELHI FROM 1980 - 1990
}

\author{
Ghufran Ahmad Khan \\ Civil and Architectural Engineering Department \\ Higher College of Technology, Muscat, Oman
}

Abstract - In this article, I have presented a case study of Delhi from 1980 to 1990 on Contemporary India. The main argument of the paper is that due to growth of population Housing became the major problem of that specified time period. Urbanization leads to growth in population of Delhi.

In order to get closer to the reality we need disaggregated primary surveys which can portray the picture of the development process of that time period.

Keywords - Contemporary India, Urbanization, Master Plan, Five Year Plans

\section{INTRODUCTION}

On January 1980, Indira Gandhi won election and hence congress came as a ruling party. Indian government took part in bid to host the ASIAN GAMES in 1982.India's GDP increases from $3.5 \%$ in 1970 's to $5.5 \%$ in 1980 's.Urbanization leads to growth in population of Delhi.

Due to population growth housing became the major problem in Delhi. The 1980's were also significant to the western discourse on modernism. The 1990's saw the emergence of a new picturesque in Indian art as the country moved towards liberalisation and free market economy. Greater mobility, exposure and access to the global art scene made possible experimentation and wide range of themes, contexts and modes began to explore.

\section{ThE SECOND MASTER Plan FOR DELHI 1981 - 2001}

Major business district centers were at developing stages like Nehru Place, Bhikaji Cama Place, and Badarpur District Center have changed the skyline of Delhi. Saket District Centre was at planning stage on that time. On $5^{\text {th }}$ March Indira Gandhi ordered operation Blue Star against Sikh militant. After the assassination of Indira Gandhi, Rajiv Gandhi became the prime minister. Riots of Sikhs, Gujarat (anti reservation protests 1981-1985), and extremist groups in Punjab \& Assam took place. The main significance was focused to Indianisation. And ultimately it had resulted in many institutionalized setups and state sponsored events, the world tour festival of India exhibitions.

\author{
Afreen Khan \\ Department of Business Studies \\ Integral University, Lucknow, UP, India
}

As Delhi is not only considered as India's political center but also as the cultural and socio political locus where both international diplomatic schemes and national insecurities could be planned nurtured, hidden, contested or reformed. Rajiv Gandhi introduced a number of reforms to boost up the development process. Reforms encouraged foreign investments and therefore decreased the government restrictions on overseas currency and decreased licensing. These reforms paved the way for the rapid economic developments in the 90's

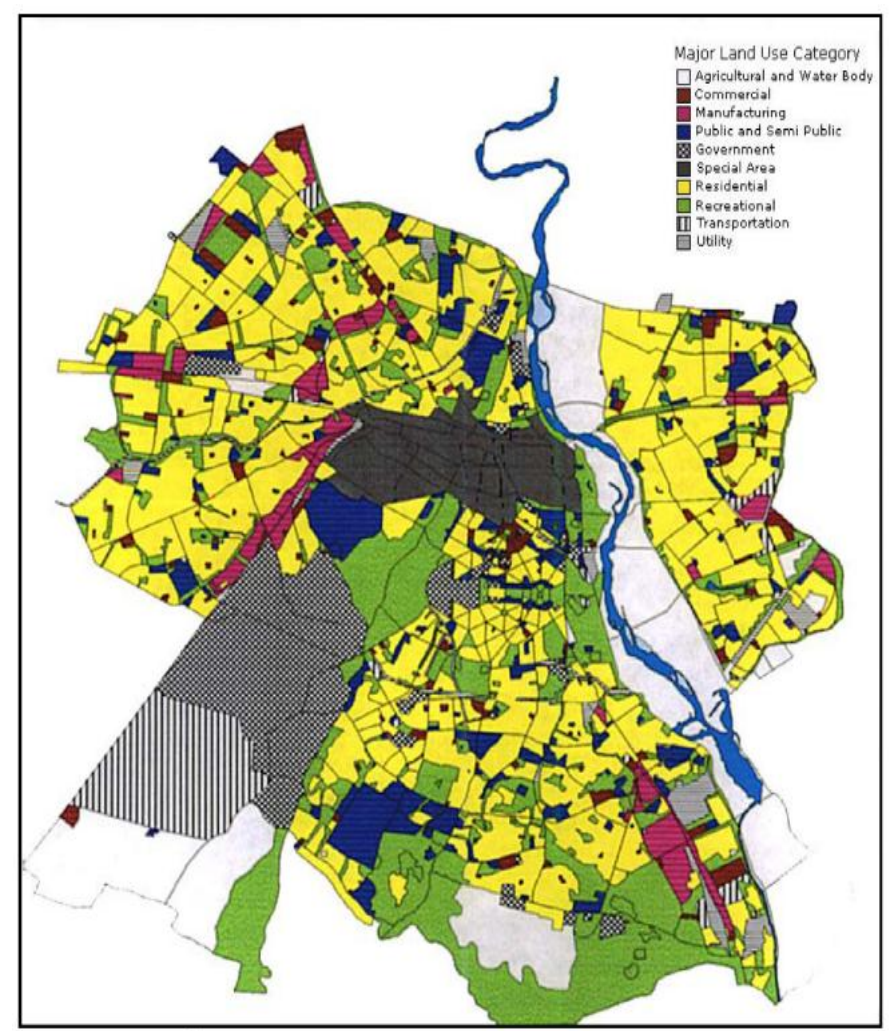

Fig. 1. Landuse Map, 1981-2001

\section{MASTER PLAN 1981-2001}

Central city area is considered to be treated as "special area". Urban heritage of Delhi to be conserved. City centre to be 
decentralized. Urban development was said to be low rise high density. There was a parameter of hierarchy which as there in development. Mixed use development was prevailed as a message by the authority.

Development of new urban integration projects like Rohini, Dwarka and Narela was treated as special areas. 21 district centre have planned to execute in reality. 2600 ha industrial area developed. MRTS network planned to bring much needed connectivity. Land fill sites converted into large greens such as Indraprastha Park. 14 sports centre were developed for variety of sport activities.

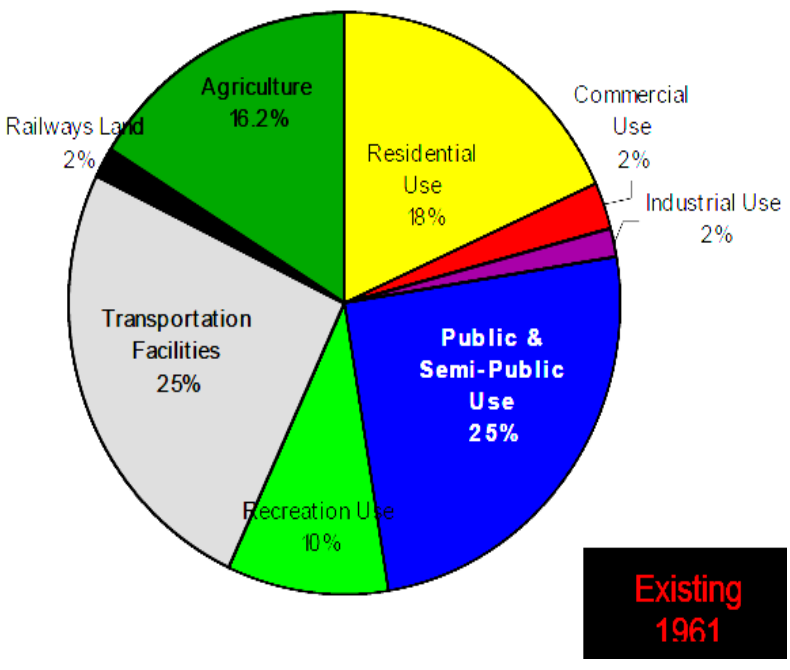

Fig. 2. Existing Landuse Map, 1961

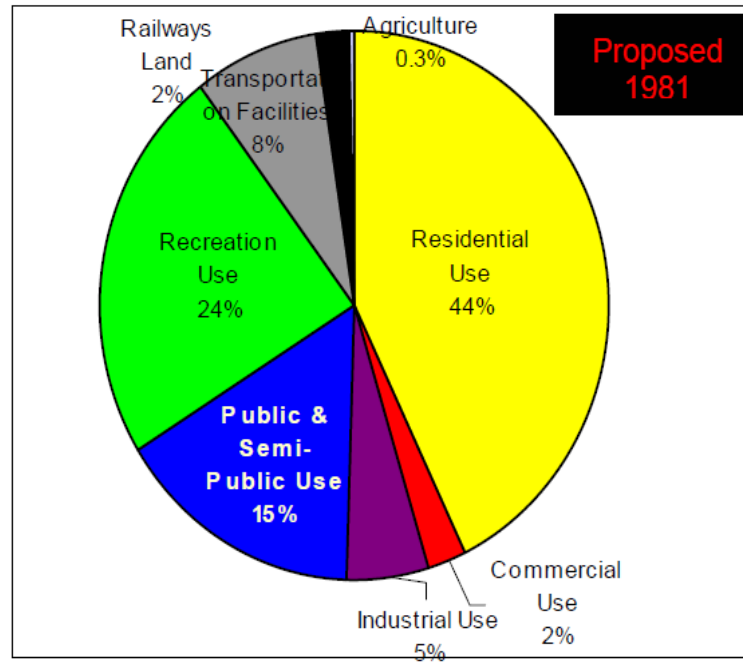

Fig. 3. Proposed Landuse Map, 1981

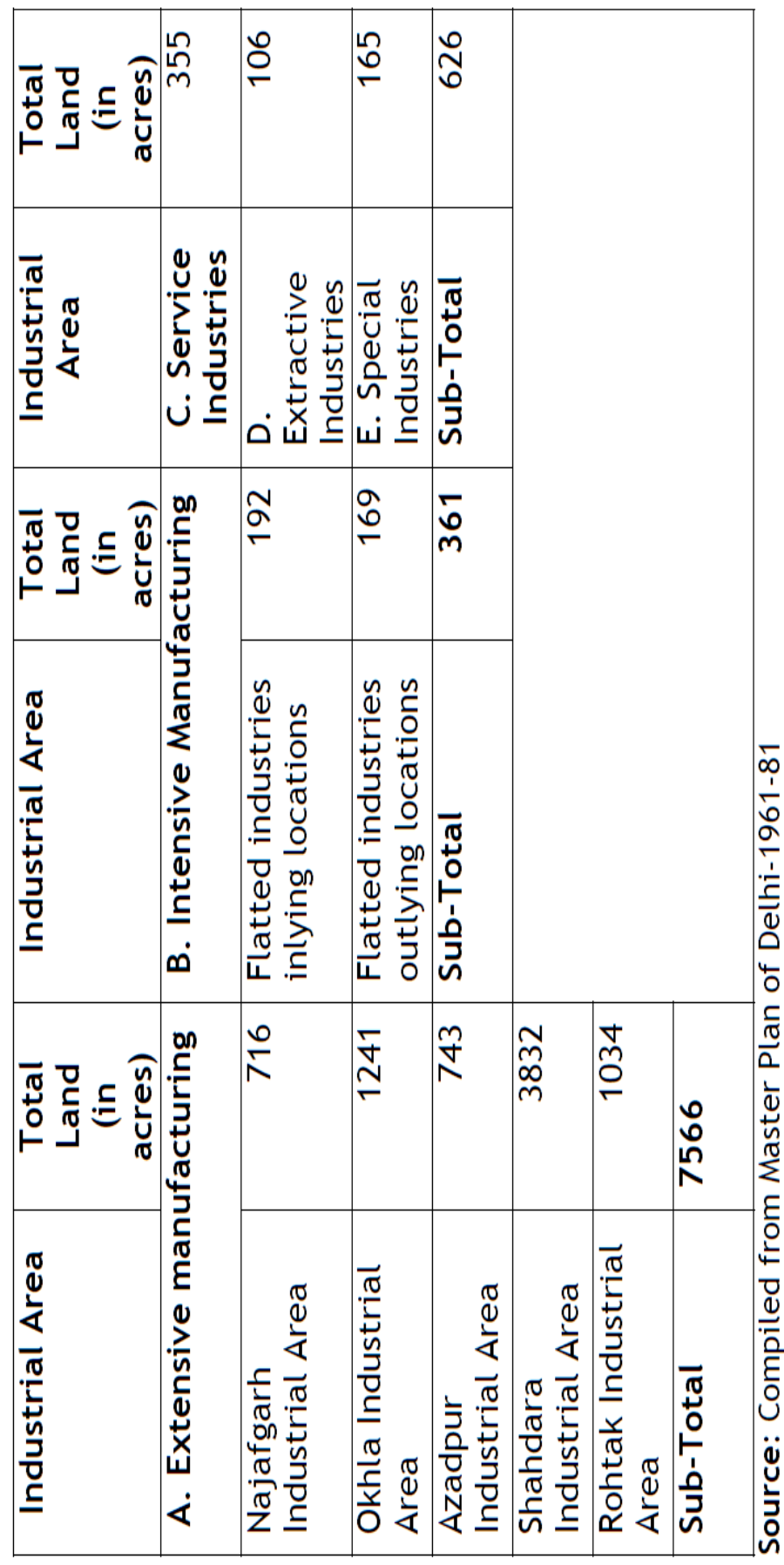

Table -1 Proposed Location of Industrial Estates and Zones, 1981 


\section{FIVE YEAR PLANS}

\section{A. Sixth five year plan (1981-1985) -}

During this time the Indian currency was devalued. This led to dramatic increase in the number of foreign travelers in India. Thus it had helped India to become a tourist destination. It aimed at development in the Information Technology.

Fig. 4. Major Developments

\begin{tabular}{|c|c|c|}
\hline Stadiums & Hotels & Flyovers \\
\hline $\begin{array}{c}\text { Jawahar Lal Nehru } \\
\text { Indira Gandhi } \\
\text { Indoor }\end{array}$ & Kanishka & Moolchand \\
\hline Talkatora & Taj Palace & Sewa Nagar \\
\hline $\begin{array}{c}\text { Tughlakabad } \\
\text { Firing Range }\end{array}$ & Ashok Yatri Niwas & \\
\hline
\end{tabular}

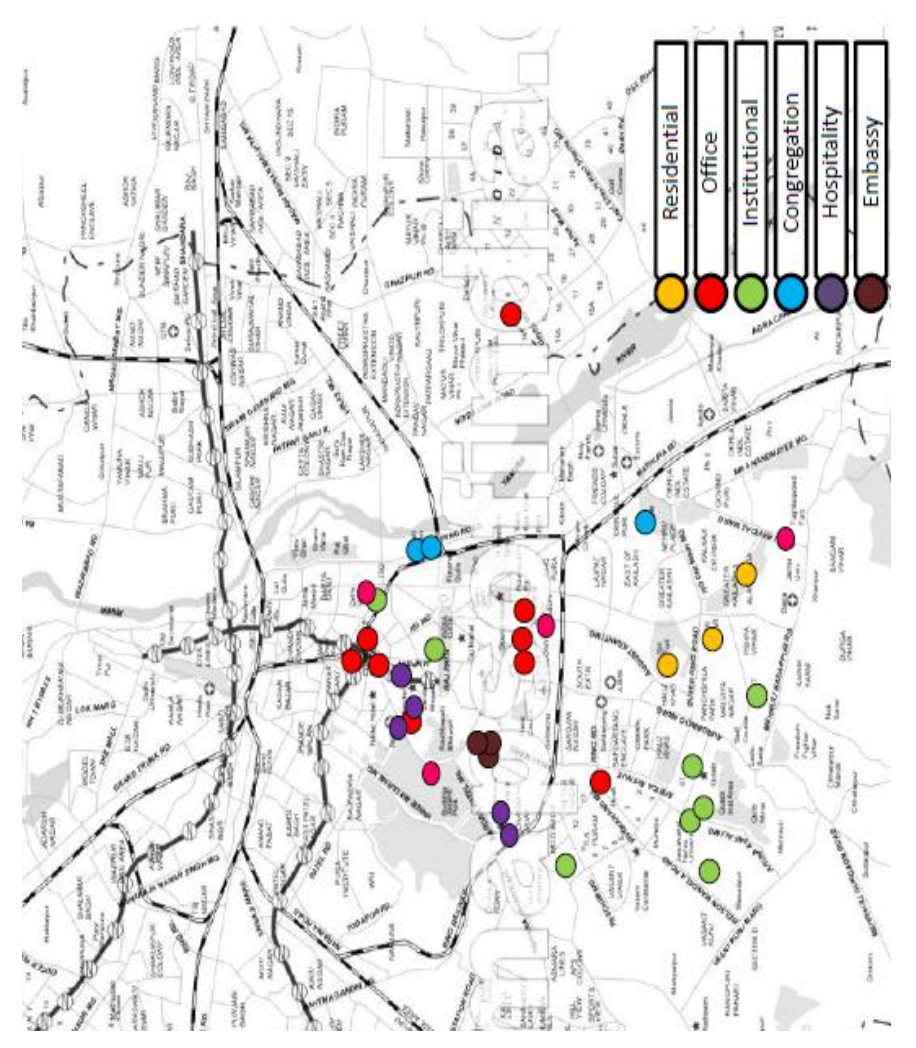

Fig. 5. Location Plan Showing Major Developments

During the time, the prime minister was Rajiv Gandhi and hence industrial development was the emphasis of this plan. The transport and communication system were also improved under this plan. The subsidized rate for articles produced got stuck from the government of India. As a consequence, the price of various goods increased leading to growth in the standard of living and the cost of living of the residents of India.

\section{B. Seventh five year plan (1986-1990) -}

Objective was to generate more scope of employment for the people of India, leads to an overall increase in productivity. Introduction and application of modern technology. DDA unable to meet forecasted demands for housing, commercial and industrial space, resulting in large scale unauthorized development, and areas with non-confusing land uses. $30 \%$ of cities population was living in planned areas.

\section{SOCIAL AND POLITICAL IMPACT: ASIAN GAMES-1982, SHOOTING THE CITY INTO LIMELIGHT}

City was prepared to host the largest event, led to construction of numerous stadiums, flyovers, hotels and the games village in a span of 20 months. In the construction, frenzy that preceded the Asian Games, lakhs of workers entered the city. Workers were often paid lower than the minimum wages and forced to live in temporary jhuggies that a large mass never moved out of. Delhi Ring Railway was started in 1982. Appu Ghar (House of Appu) was constructed after the Asian Games. It also brought about another major socio-economic change in India, when the color television was introduced in India for the first time.

\section{CONCLUSION}

In 1980's, Delhi was considered as a locus of accumulated social energy with regard to cultural production in India. 1980's was an important phase in contemporary international architecture where modernism has come to an end followed by post modernism and was taking interest in architecture of developing countries like India. Delhi was one of the major centre of growth and development of India. In this period, many foreign return architects like Raj Rewal, Achyut P. Kanvinde and Ranjit Sabhiki created various government institutions and change the skyline of Delhi in terms of architectural developments. Mostly all the buildings were built according to the climatic conditions. Most of the emphasis was on the massing and feeling of grandeur. Traditional concepts and locally available materials were being used by the architects at that time period. Few of the architects had experienced some new concepts also. 


\section{REFERENCES}

[1] H. Venkatsubbiah, Enterprise and Economic Change: 50 Years of FICCI (New Delhi: Vikas Publishing House, 1977), pp. 169-72.

[2] Francine R. Frankel, India's Political Economy (New Delhi: Oxford University Press, 2005), chapter 4.

[3] I. G. Patel, Glimpses of Indian Economic Policy(New Delhi: Oxford University Press, 2003), chapter 2.

[4] Dwijendra Tripathi and Jyoti Jumani, The Concise Oxford History of Indian Business (New Delhi: Oxford University Press, 2007), chapter 12.

[5] K. Sundaram, "Political Response to the 1966 Devaluation-2," Economic and Political Weekly, September 19, 1972, p. 1883.

[6] Awasthi, D.N. (1991): Regional Patterns of Industrial Growth in India. Concept Publishing Company, New Delhi. (E)

[7] Misra, G.P. (1985): Regional Structure of Development \& Growth in India. Ashish Publishing House, New Delhi. (E)

[8] Tiwari, P.C. (1988): Regional Development and Planning in India. Criterion Publications, New Delhi. 199-224.

[9] Human Development Index Report (1981): Institute of Applied Manpower Research. Planning Commission. Government of India, New Delhi. (E)

[10] Okahashi, H. (2013): Development of Contemporary India Area Studies as Part of Geographical Studies in Japan since the 1980s. Geographical Review of Japan Series B, 86(1), 40-51. (JE)

[11] Patnaik, P. (2012): Industrial Development in India since Independence. Social Scientist, Vol. 7, No. 11, 3-19. (E)

[12] https://www.livemint.com/Politics/QYaohpsFZCqbxR11rc y4JK/70-years-in-Indian-politics-and-policy.html

[13] https://www.indiatoday.in/magazine/coverstory/story/20051226-india-in-1980-major-events-andhappenings-786336-2005-12-26

[14] https://www.news18.com/photogallery/india/in-pics-100years-of-delhi-as-indias-capital-816131-8.html

[15] http://www.biennalejogja.org/2011/article/thecontemporary-and-indian-contemporary-art-21stcentury/?lang=en

[16] Master plan of Delhi 1961-81 